\title{
Variation of Proteins in Subcellular Sarcoplasmic Fractions of Chicken Red and White Skeletal Muscles Influenced by Under-nutrition ${ }^{\dagger}$
}

\author{
Ali Asghar, ${ }^{\dagger}{ }^{\dagger}$ Jun-Ichiro Morita, Kunihiko SAmejImA* \\ and Tsutomu YASUI \\ Department of Animal Science, Faculty of Agriculture, \\ Hokkaido University, Sapporo 060, Japan \\ *Department of Dairy Science, The College of Dairying, \\ Ebetsu-shi, Hokkaido 069-01, Japan
}

Received December 9, 1985

\begin{abstract}
The influence of under-nutrition (sub-maintenance feeding) and ad libitum feeding on the deposition of proteins in different subcellular sarcoplasmic fractions of red (tonic) and white (phasic) muscles of growing broilers was investigated. The relative concentration of overall sarcoplasmic proteins was lesser in red than in white muscles from ad libitum fed broilers. The content of mitochondrial proteins was slightly more and that of lysosomal and microsomal proteins and of true soluble proteins was lesser in red than in white muscles. Besides, the relative amount of some specific molecular weight proteins in each subcellular fractions differed by more than $50 \%$ between red and white muscle.

There was also conspicuous differences in the influence of under-nutrition on the proteins in red and white muscles. Some reduction in mitochondrial, lysosomal, microsomal, and soluble protein content occurred only in white muscle, whereas little change was found in subcellular fractions in red muscle from underfed broilers. The relative amount of some proteins in each subcellular fraction of both muscles remained unaffected, and that of others either decreased or increased more than 20 to $50 \%$ due to nutritional stress.
\end{abstract}

The proteins in skeletal muscle are in a dynamic state, being renewed continuously during normal growth and development as well as in the steady state condition of an animal. However, an insufficient supply of feed for a long time accelerates the catabolism of muscle proteins to meet the metabolic demand for a gluconeogenic carbon source, when the glycogen and fat reserves are depleted to a critical level in the body. The breakdown of muscle protein also helps to maintain the amino acid pool for the synthesis of those proteins which are required by the cells for survival. Thus a net loss in muscle mass due to underfeeding is caused by a decrease in protein synthesis and by an increase in protein degradation. ${ }^{\sim 4)}$

It is well documented that tonic (slow) and phasic (fast) muscles which are rich respectively in red and white fibers, differ from each other ultrastructurally, ${ }^{5,6)}$ biochemically, ${ }^{7,8)}$ enzymatically, ${ }^{9 \sim 11)} \quad$ histochemically, ${ }^{12,13)}$ ontogenetically, ${ }^{14)}$ and physiologically. ${ }^{15)}$ There is also substantial difference in the overall protein turnover rate between red and white muscles, ${ }^{16,17)}$ being higher in the former than in the latter. These facts attracted us to explore if the deposition of different proteins of subcellular fractions is affected in skeletal muscle by under-nutrition, and to examine whether or

${ }^{\dagger}$ This work was supported by a Grant-in Aid for Scientific Research (Project No. 58430022 1984) from the Ministry of Education, Science and Culture of Japan.

${ }^{\dagger}+$ Present address: Department of Food Science and Human Nutrition, Michigan State University, East Lansing, Michigan, 48824, U.S.A. 
not the effect of under-nutrition (submaintenance feeding) is similar on different proteins in subcellular fractions of red and white muscles. The first part of our study, which deals with the proteins of sarcoplasm and its subcellular fractions of red and white muscle from broilers as influenced by undernutrition (sub-maintenance feeding) is presented in this manuscript.

\section{MATERIALS AND METHODS}

The growth history of broilers and the experimental design have already been described fully in our earlier communication. ${ }^{18)}$ Briefly, one group of broiler chickens that received ad libitum feed from hatching to 8 weeks of age was put onto sub-maintenance feeding for 4 weeks before being slaughtered. The other group continued on ad libitum feed until killing as a control. The broilers were killed in pairs (one from each group) and the experiment was planned in a way that the consecutive pairs of broilers due to be killed were distributed over several days so that the time sequence permitted analysis.

Extraction of sarcoplasmic proteins. Immediately after bleeding the broilers, the leg and breast muscles were removed from the carcass, cooled in crushed ice, and minced in a mincer (sieve size $5 \mathrm{~mm}$ ). All the subsequent operations were done in a cold room $\left(4^{\circ} \mathrm{C}\right)$. One hundred grams of each minced sample, from leg or breast muscles, was dispersed in $800 \mathrm{ml}$ of chilled sarcoplasmic-proteinextracting solution $(0.25 \mathrm{M}$ sucrose, $10 \mathrm{~mm}$ Tris- $\mathrm{HCl}$ buffer, pH 7.5, and $10 \mathrm{~mm}$ EDTA), and homogenized with a Hitachi VA- 835 homogenizer at $12,000 \mathrm{rpm}$ for $2 \mathrm{~min}$. The resulting slurry was centrifuged at $500 \times g$ for $10 \mathrm{~min}$ to precipitate myofibrillar and connective tissue fractions.

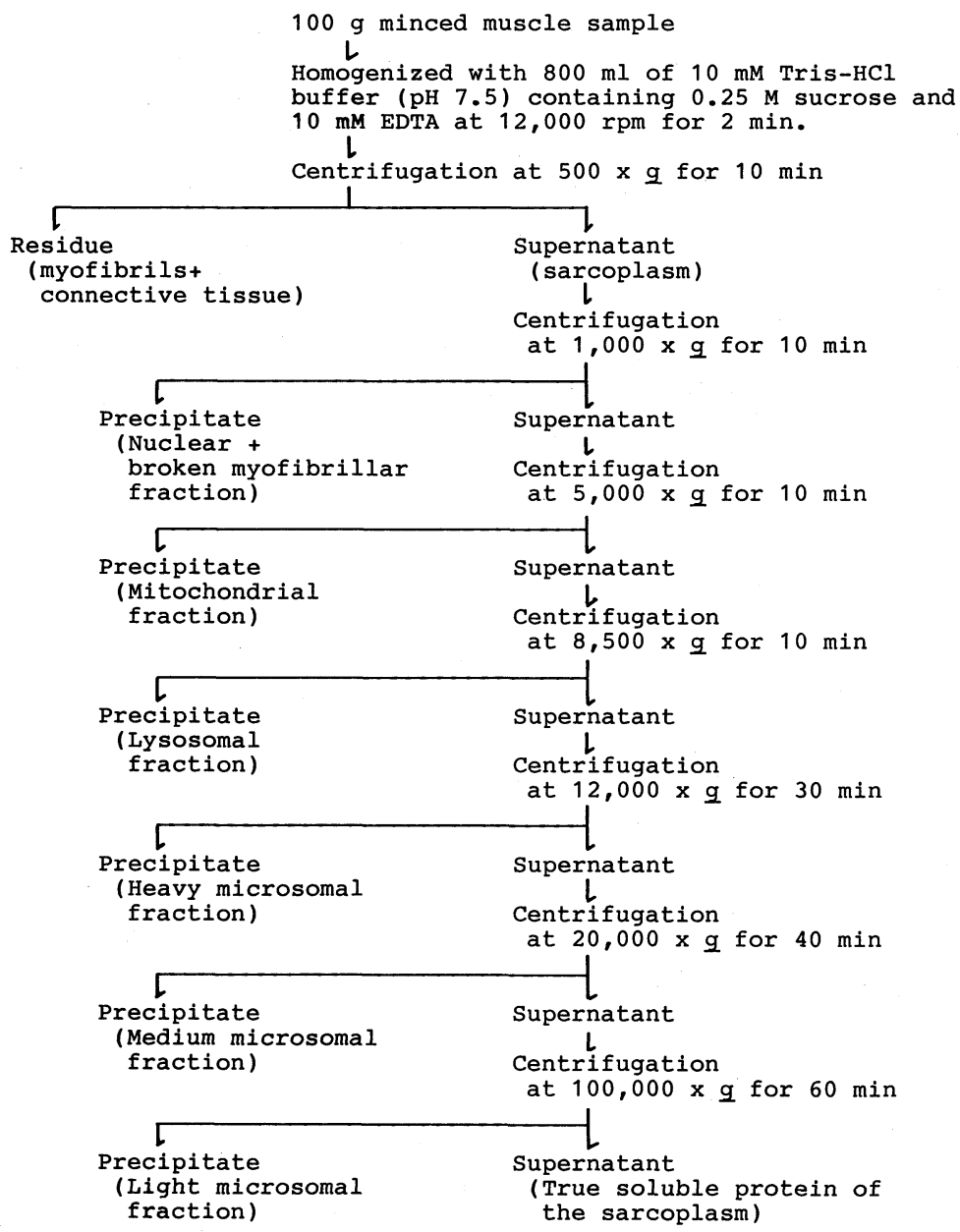

Fig. 1. Flow-sheet Diagram Showing the Separation of Different Subcellular Sarcoplasmic Fractions from Muscle Sample by Differential Centrifugation. 
The sarcoplasm was collected and the residue was homogenized again with $400 \mathrm{ml}$ of the above-mentioned buffer for $1 \mathrm{~min}$ and centrifuged. The sarcoplasmic extracts were pooled, and the residue was saved for the extraction of myofibrillar and cytoskeletal proteins.

Subcellular fractionation of sarcoplasmic extract. Basically, the differential centrifugation procedure of de Duve et $a l .{ }^{19)}$ was followed with slight modifications ${ }^{20,21)}$ to separate different subcellular fractions (nuclear, mitochondrial, microsomal consisting of heavy, medium, and light fractions, and true soluble proteins) as depicted in Fig. 1. It may be pointed out that this differential centrifugation technique, though it yields a quite rough fractionation of subcellular components, serves the purpose of finding differences well, which was the central objective in our study. The precipitate of each fraction, obtained by differential centrifugation, was dispersed in $10 \mathrm{~mm}$ phosphate buffer ( $\mathrm{pH}$ 7.2) using a glass-Teflon homogenizer, for further analysis.

Protein measurement. The protein content in each fraction was measured by a modified version of the method of Lowry et al., ${ }^{22)}$ as described by Peterson. ${ }^{23)}$ In this procedure the interference of non-protein substances in the extract is largely eliminated by precipitating the proteins in each fraction by adding $0.2 \mathrm{ml}$ of $0.15 \%$ sodium deoxycholate and $0.2 \mathrm{ml}$ of $72 \%$ trichloroacetate (TCA) to $2 \mathrm{ml}$ of protein extract. The precipitate was washed with $8 \%$ TCA, and finally dissolved in a reagent consisting of SDS, $\mathrm{CuSO}_{4}$-tartrate- $\mathrm{Na}_{2} \mathrm{CO}_{3}, \mathrm{NaOH}$, and phenol. ${ }^{23)} \mathrm{A}$ standard curve was constructed with bovine serum albumin of known protein concentration.

Polyacrylamide gel electrophoresis with sodium dodecyl sulfate ( $S D S-P A G E$ ). SDS-PAGE was done by Laemmli's method $^{24)}$ The TCA-precipitated proteins from each subcellular fraction of sarcoplasm were dissolved in a solution of $100 \mathrm{~mm}$ Tris-glycine buffer, $\mathrm{pH} 8.8,2 \% \mathrm{SDS}, 1 \% 2-$ mercaptoethanol, and $5 \mathrm{~mm}$ EDTA and heated in boiling water for $5 \mathrm{~min}$, and then dialyzed against a buffer consisting of $25 \mathrm{~mm}$ Tris- $\mathrm{HCl}$ (pH 7.2), $2 \% \mathrm{SDS}$, and $0.1 \% 2$ mercaptoethanol overnight. The protein was measured as described above, and the known concentration of protein was put on $1 \mathrm{~mm}$ thick and $70 \mathrm{~mm}$ long $10 \%$ polyacrylamide slab gels in the presence of $0.1 \%$ SDS. A standard curve of known molecular weight protein was constructed to find the molecular weight of proteins in test samples. The differences between the amounts of different molecular weight proteins in each subcellular fraction of sarcoplasm from red and white muscles of underfed and control broilers were found using densitometric data from a Toyo DVC-33C densitometer.

Statistical analysis. Two-way analysis of variance ${ }^{25)}$ was applied to the numerical data to find the level of significance of the results.

\section{RESULTS}

\section{Protein content of different subcellular sarco-} plasmic fractions from red and white muscles

Table I shows that the total sarcoplasmic protein content was significantly higher in white (breast) than in red (leg) muscle from well-nourished broilers $(p<0.5)$. On the other hand, no consistent difference in the nuclear fraction was visible between muscles because of wide variation in the estimate as is apparent from the magnitude of standard deviation values. This possibly arose by contamination of this fraction with broken myofibrils to varying degrees during the homogenizing step in different broilers. However, the mitochondrial fraction was higher in red than in white muscle $(p<0.05)$. The apparent content of lysosomal and all the three microsomal fractions (heavy, medium, and light) tended to be slightly more in white than in red muscle (on a muscle weight basis), but all these fractions were a larger proportion of sarcoplasmic protein in red than in white muscle. The apparent concentration of true soluble proteins in $100,000 \times g$ supernatant was higher in white than in red muscle, but it constituted about $88 \%$ of the total sarcomplasmic protein $(1,000 \times g$ extract $)$ in both muscles.

\section{Effects of under-nutrition on protein content of subcellular sarcoplasmic fractions from red and white muscles}

Table I also indicates that the total sarcoplasmic protein content decreased to some extent in white (breast) muscle, but little change was apparent in red (leg) muscle as the result of under-nutrition. The mitochondrial fractions tended to be higher in red and lower in white muscle from underfed broilers than in their respective controls. The content of lysosomal and microsomal fractions was slightly reduced in white muscle due to under-nutrition, but in red muscle no change was apparent in these fractions as a result of under-nutrition. The content of soluble protein $(100,000 \times g$ supernatant) also remained fairly stable in red muscle, whereas some reduction did occur in 
Table I. Protein Content of Different Subcellular Sarcoplasmic Fractions of Leg (Red) AND Breast (White) MusCles From ad libitum Fed AND UNDERFED BroILERS

\begin{tabular}{|c|c|c|c|c|}
\hline \multirow[b]{2}{*}{$\begin{array}{l}\text { Subcellular } \\
\text { fraction }\end{array}$} & \multicolumn{2}{|c|}{ ad libitum Fed broilers } & \multicolumn{2}{|c|}{ Underfed broilers } \\
\hline & $\begin{array}{c}\text { Leg } \\
\text { (red muscle) } \\
(\mathrm{mg} /\end{array}$ & $\begin{array}{l}\text { Breast } \\
\text { (white muscle) } \\
\text { muscle) }\end{array}$ & $\begin{array}{c}\text { Leg } \\
\text { (red muscle) } \\
(\mathrm{mg} / 1\end{array}$ & $\begin{array}{l}\text { Breast } \\
\text { (white muscle) } \\
\text { nuscle) }\end{array}$ \\
\hline Sarcoplasmic fraction & $2,990 \pm 759^{a}$ & $4,700 \pm 1,332$ & $3,007 \pm 850^{\mathrm{a}}$ & $4,062 \pm 1,144$ \\
\hline $\begin{array}{c}\text { Nuclear plus broken } \\
\text { myofibril fraction }\end{array}$ & $294 \pm 120^{\mathrm{a}}$ & $254 \pm 220^{\mathrm{a}}$ & $325 \pm 122^{\mathrm{a}}$ & $214 \pm 174^{\mathrm{a}}$ \\
\hline Mitochondrial fraction & $91.3 \pm 16.8$ & $84.0 \pm 23.9$ & $117.3 \pm 5.3$ & $41.0 \pm 9.4$ \\
\hline Lysosomal fraction & $22.6 \pm 6.6^{\mathrm{a}}$ & $27.7 \pm 8.5$ & $21.1 \pm 6.7^{\mathrm{a}}$ & $24.2 \pm 7.0$ \\
\hline $\begin{array}{l}\text { Heavy microsomal } \\
\text { fraction }\end{array}$ & $28.7 \pm 11.9^{\mathrm{a}}$ & $30.1 \pm 9.3$ & $31.2 \pm 8.8^{\mathrm{a}}$ & $22.1 \pm 6.6$ \\
\hline $\begin{array}{l}\text { Medium microsomal } \\
\text { fraction }\end{array}$ & $32.7 \pm 14.8^{\mathrm{a}}$ & $37.0 \pm 14.7$ & $32.7 \pm 11.2^{\mathrm{a}}$ & $28.3 \pm 10.0$ \\
\hline $\begin{array}{l}\text { Light microsomal } \\
\text { fraction }\end{array}$ & $69.7 \pm 2.6^{\mathrm{a}}$ & $74.4 \pm 8.3$ & $71.1 \pm 5.0^{\mathrm{a}}$ & $60.6 \pm 8.1$ \\
\hline True soluble proteins & $2,650 \pm 64^{\mathrm{a}}$ & $4,150 \pm 88$ & $2,560 \pm 54^{\mathrm{a}}$ & $3,636+93$ \\
\hline $\begin{array}{l}\text { Water } \\
\quad(\% \text { in muscle })\end{array}$ & $76.12 \pm 0.28$ & $75.41 \pm 0.35$ & $76.82 \pm 0.18$ & $75.98 \pm 0.22$ \\
\hline
\end{tabular}

The figures carrying the same letter in a horizontal line are not significantly different from each other $(p>0.05)$. The other data show the arithmetical mean value \pm standard deviation.

this fraction of white muscle from broilers which experienced nutritional stress for about 4 weeks.

Comparison of different proteins in each subcellular fraction of sarcoplasm from red and white muscle

From the densitometer data of SDS-PAGE, the differences were computed between various proteins which were resolved from different subcellular sarcoplasmic fractions. The results are consolidated in Table II, for comparing red and white muscle from ad libitum fed (control), and those from undernourished broilers.

Proteins in $1,000 \times g$ precipitate. The $1,000 \times$ $g$ precipitate of the sarcoplasmic extract represents mainly the nucleic fraction, ${ }^{19)}$ and some broken myofibrils of muscle fibers. On SDSPAGE, this fraction was resolved into various proteins with molecular weights from $200 \mathrm{~K}$ $(200 \times 1,000)$ to $<20 \mathrm{~K}$ (less than $20 \mathrm{~K}$ ) (Fig. 2(a)). The proportion of $170 \sim 200 \mathrm{~K}, 48 \mathrm{~K}$, and $35 \sim 37 \mathrm{~K}$ protein was higher and those of $60 \sim 140 \mathrm{~K}$ and $20 \sim 21 \mathrm{~K}$ was lower in this fraction from white than from red muscle (Table II). However, the relative content of
$59 \mathrm{~K}, 43 \mathrm{~K}, \sim 30 \mathrm{~K}$, and low molecular weight $(<20 \mathrm{~K})$ proteins was almost identical in both types of muscles.

Under-nutrition of broilers caused more than $20 \%$ reduction in the amount of $60 \sim$ $140 \mathrm{~K}, 43 \mathrm{~K}$, and low molecular weight $(<20$ $\mathrm{K})$ proteins, and increase in $59 \mathrm{~K}, 48 \mathrm{~K}, 35$ $37 \mathrm{~K}, \sim 30 \mathrm{~K}$, and $20 \sim 21 \mathrm{~K}$ protein content in white (breast) muscle. In contrast, some protein species in this fraction of red (leg) muscle from underfed broilers remained fairly stable, except that the relative amount of $170 \sim 200 \mathrm{~K}$ and $35 \sim 37 \mathrm{~K}$ proteins increased, and of $60 \sim$ $140 \mathrm{~K}, 48 \mathrm{~K}$, and $\sim 30 \mathrm{~K}$ protein decreased more than $20 \%$.

Proteins in 5,000 $\times$ g precipitate. The 5,000 $\times$ $g$ precipitate comprised mainly the mitochondrial fraction of the sarcoplasm..$^{1921)}$ Several proteins were resolved from this fraction on SDS-PAGE (Fig. 2(b)). Conspicuous differences in relative concentration of several proteins were observed in this fraction between red and white muscle (Table II). For example, the content of $160 \mathrm{~K} \leq$ ( $160 \mathrm{~K}$ or more), $90 \mathrm{~K}$, and $43 \mathrm{~K}$ proteins was higher and that of $60 \mathrm{~K}$, $45 \sim 50 \mathrm{~K}$, and $22 \mathrm{~K}$ was lower in white than in 
(a)

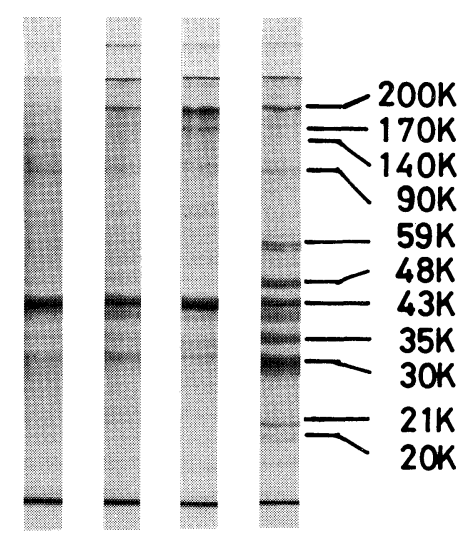

CL CB SL SB

(d)

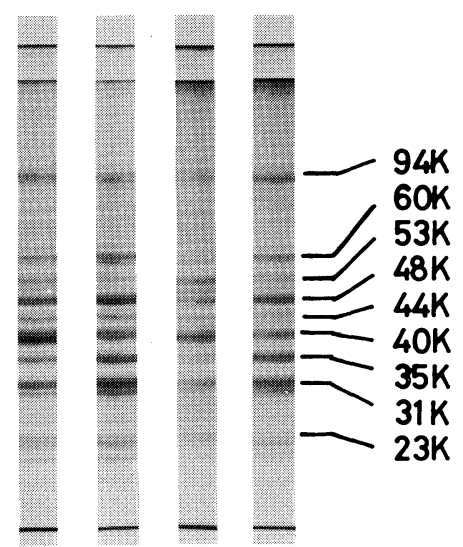

CL CB SL SB (b)

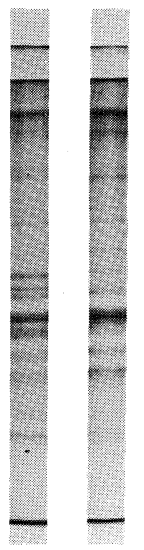

CL $\quad$ CB $\quad S L \quad S B$

(e)
(C)

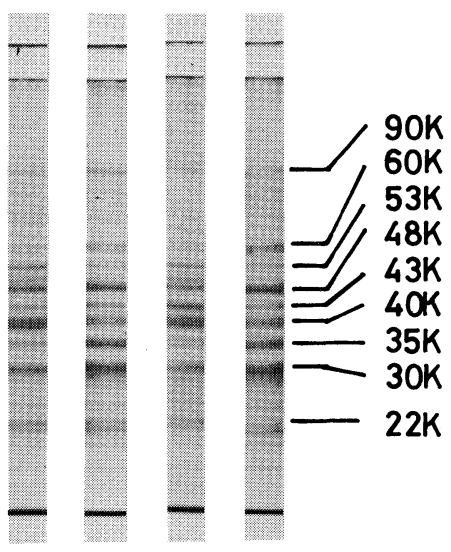

CL CB SL SB
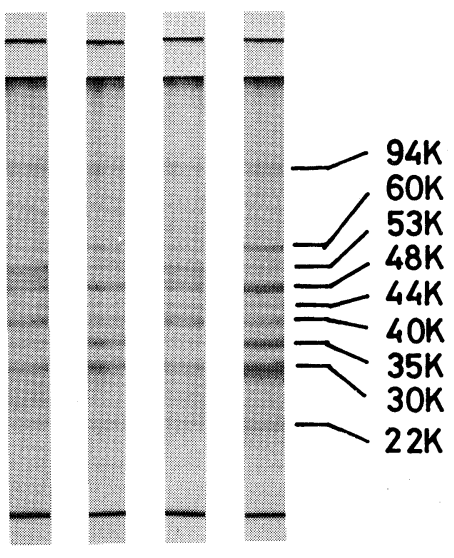

CL CB SL SB $(\mathbf{f})$

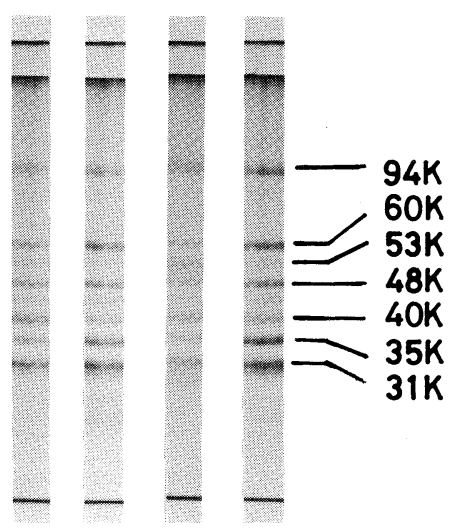

CL CB SL SB

( $\mathbf{g}$ )

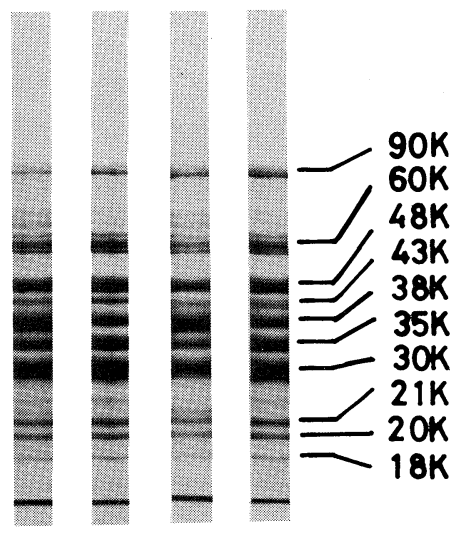

CL CB SL SB
FIG. 2. SDS-Polyacrylamide Gel Electrophoretic Profiles of the Fractions from Sarcoplasmic Extracts of Leg (Red) and Breast (White) Muscles of Broilers.

Precipitate at $1,000 \times g$ (nuclear fraction) (a), 5,000 $\times g$ (mitochondrial fraction) (b), $8,500 \times g$ (lysosomal fraction) (c), $12,000 \times g$ (heavy microsomal fraction) (d), 20,000 $\times g$ (medium microsomal fraction) (e), and 100,000 $\times g$ (light microsomal fraction) (f), and supernatant at $100,000 \times g$ (true soluble proteins) $(\mathrm{g})$.

$\mathrm{CL}$ and $\mathrm{CB}$ represent respectively the leg and breast muscles from ad libitum fed broilers, whereas SL and SB represent respectively the leg and breast muscles from nutritionally stressed (sub-maintenance fed) broilers. 
Table II. Relative Difference in the Content of Various Molecular Weight Proteins in Different Subcellular Sarcoplasmic Fractions of Red (Leg) and White (Breast) Muscles from ad libitum Fed and Underfed Broilers

\begin{tabular}{|c|c|c|c|c|c|}
\hline \multirow{2}{*}{$\begin{array}{l}\text { Subcellular } \\
\text { fraction }\end{array}$} & \multirow{2}{*}{$\begin{array}{l}\text { molecular } \\
\text { weight of } \\
\text { proteins }\end{array}$} & \multicolumn{2}{|c|}{ ad libitum Fed broilers } & \multicolumn{2}{|c|}{ Underfed broilers } \\
\hline & & Leg & Breast & Leg & Breast \\
\hline \multirow{9}{*}{$\begin{array}{l}\text { 1. Nuclear fraction } \\
(1,000 \times g \text { ppt. })\end{array}$} & $170 \sim 200 \mathrm{~K}$ & Low*** & High $^{* * *}$ & I. $* * *$ & N.S.C. \\
\hline & $60 \sim 140 \mathrm{~K}$ & High* & Low* & D.* & D.* \\
\hline & $59 \mathrm{~K}$ & N.S.D. & N.S.D. & N.S.C. & I. ${ }^{* *}$ \\
\hline & $48 \mathrm{~K}$ & Low* & High* & D.* & I. $* * *$ \\
\hline & $43 \mathrm{~K}$ & N.S.D. & N.S.D. & N.S.C. & D.* \\
\hline & $35 \sim 37 \mathrm{~K}$ & Low* & High* & I.* & I. $* * *$ \\
\hline & $\sim 30 \mathrm{~K}$ & N.S.D. & N.S.D. & D.* & $\mathrm{I} . * * *$ \\
\hline & $20 \sim 21 \mathrm{~K}$ & High* & Low* & N.S.C. & $\mathrm{I}^{* *}$ \\
\hline & $<20 \mathrm{~K}$ & N.S.D. & N.S.D. & N.S.C. & D.* \\
\hline \multirow{8}{*}{$\begin{array}{l}\text { 2. Mitochondrial } \\
\text { fraction } \\
(5,000 \times g \text { ppt. })\end{array}$} & $160 \mathrm{~K} \leq$ & Low* & High* & N.S.C. & D. $* *$ \\
\hline & $90 \mathrm{~K}$ & Low* & High* & N.S.C. & I.* \\
\hline & $60 \mathrm{~K}$ & High* & Low* & N.S.C. & I. $* * *$ \\
\hline & $45 \sim 50 \mathrm{~K}$ & $\mathrm{High}^{* * *}$ & Low $* * *$ & D.* & I. $* * *$ \\
\hline & $43 \mathrm{~K}$ & Low* & High* & I.* & D.* \\
\hline & $30 \sim 40 \mathrm{~K}$ & N.S.D. & N.S.D. & N.S.C. & I. *** \\
\hline & $22 \mathrm{~K}$ & $\mathrm{High}^{* *}$ & Low** & N.S.C. & I.* \\
\hline & $<22 \mathrm{~K}$ & N.S.D. & N.S.D. & N.S.C. & D.* \\
\hline \multirow{8}{*}{$\begin{array}{l}\text { 3. Lysosomal and } \\
\text { peroxisomal } \\
\text { fraction } \\
(8,500 \times g \text { ppt. })\end{array}$} & $90 \mathrm{~K}$ & Low* & High* & N.S.C. & N.S.C. \\
\hline & $60 \mathrm{~K}$ & N.S.D. & N.S.D. & N.S.C. & I.** \\
\hline & $53 \mathrm{~K}$ & High* & Low* & N.S.C. & N.S.C. \\
\hline & $48 \mathrm{~K}$ & N.S.D. & N.S.D. & N.S.C. & I. $* *$ \\
\hline & $40 \mathrm{~K}$ & High* & Low* & N.S.C. & N.S.C. \\
\hline & $35 \mathrm{~K}$ & Low** & High** & N.S.C. & N.S.C. \\
\hline & $30 \mathrm{~K}$ & Low* & High* & N.S.C. & N.S.C. \\
\hline & $\leq 22 \mathrm{~K}$ & High* & Low* & N.S.C. & N.S.C. \\
\hline \multirow{9}{*}{$\begin{array}{l}\text { 4. Microsomal (heavy) } \\
\text { fraction } \\
(12,000 \times g \text { ppt. })\end{array}$} & $94 \mathrm{~K}<$ & High* & Low* & I.** & $\mathrm{I} . * * *$ \\
\hline & $94 \mathrm{~K}$ & N.S.D. & N.S.D. & N.S.C. & I.* \\
\hline & $60 \mathrm{~K}$ & Low* & High* & N.S.C. & N.S.C. \\
\hline & $53 \mathrm{~K}$ & High* & Low* & I. ${ }^{* *}$ & I.* \\
\hline & $48 \mathrm{~K}$ & Low $* * *$ & $\operatorname{High}^{* * *}$ & D. $* *$ & D. $* *$ \\
\hline & $40 \mathrm{~K}$ & High** & Low** & D. $* *$ & D. $* * *$ \\
\hline & $35 \mathrm{~K}$ & Low $* * *$ & $\mathrm{High}^{* * *}$ & N.S.C. & N.S.C. \\
\hline & $\sim 31 \mathrm{~K}$ & Low* & High* & D.* & D. $*$ \\
\hline & $\leq 23 \mathrm{~K}$ & N.S.D & N.S.D. & N.S.C. & D.* \\
\hline \multirow{6}{*}{$\begin{array}{l}\text { 5. Microsomal (medium) } \\
\text { fraction } \\
(20,000 \times g \text { ppt. })\end{array}$} & $60 \mathrm{~K}$ & Low** & High** & N.S.C. & I.* \\
\hline & $48 \mathrm{~K}$ & Low* & High* & N.S.C. & I.* \\
\hline & $40 \mathrm{~K}$ & High* & Low* & N.S.C. & N.S.C. \\
\hline & $35 \mathrm{~K}$ & Low $* * *$ & $\mathrm{High}^{* * *}$ & D.* & I.* \\
\hline & $30 \mathrm{~K}$ & Low $* * *$ & High $^{* * *}$ & I.* & I. $* *$ \\
\hline & $\leq 22 \mathrm{~K}$ & High* & Low* & N.S.C. & N.S.C. \\
\hline \multirow{8}{*}{$\begin{array}{l}\text { 6. Microsomal (light) } \\
\text { fraction } \\
(100,000 \times g \text { ppt. })\end{array}$} & $94 \mathrm{~K}$ & N.S.D. & N.S.D. & N.S.C. & I.* \\
\hline & $60 \mathrm{~K}$ & Low** & $\mathrm{High}^{* *}$ & I.* & I.* \\
\hline & $53 \mathrm{~K}$ & $\mathrm{High}^{* * *}$ & Low*** & N.S.C. & N.S.C. \\
\hline & $48 \mathrm{~K}$ & N.S.D. & N.S.D. & D.* & N.S.C. \\
\hline & $40 \mathrm{~K}$ & High* & Low* & N.S.C. & N.S.C. \\
\hline & $35 \mathrm{~K}$ & Low $* * *$ & High*** & N.S.C. & N.S.C. \\
\hline & $31 \mathrm{~K}$ & Low** & High** $^{* *}$ & N.S.C. & I.* \\
\hline & $<31 \mathrm{~K}$ & High* & Low* & N.S.C. & N.S.C. \\
\hline \multirow{3}{*}{$\begin{array}{l}\text { 7. True soluble proteins } \\
(100,000 \times g \text { sup. })\end{array}$} & $90 \mathrm{~K} \leq$ & N.S.D. & N.S.D. & I. $* * *$ & I. $* * *$ \\
\hline & $\sim 60 \mathrm{~K}$ & Low* & High* & D.* & N.S.C. \\
\hline & $48 \mathrm{~K}$ & Low* & High* & N.S.C. & N.S.C. \\
\hline
\end{tabular}


TABLE II. (Continued)

\begin{tabular}{|c|c|c|c|c|c|}
\hline \multirow{2}{*}{$\begin{array}{l}\text { Subcellular } \\
\text { fraction }\end{array}$} & \multirow{2}{*}{$\begin{array}{l}\text { molecular } \\
\text { weight of } \\
\text { proteins }\end{array}$} & \multicolumn{2}{|c|}{ ad libitum Fed broilers } & \multicolumn{2}{|c|}{ Underfed broilers } \\
\hline & & Leg & Breast & Leg & Breast \\
\hline & $38 \mathrm{~K}$ & High*** & Low $* * *$ & N.S.C. & N.S.C. \\
\hline & $35 \mathrm{~K}$ & Low** & High $^{* *}$ & N.S.C. & D.* \\
\hline & $\sim 30 \mathrm{~K}$ & Low* & High* & N.S.C. & N.S.C. \\
\hline & $21 \mathrm{~K}$ & Low** & High** & N.S.C. & N.S.C. \\
\hline
\end{tabular}

N.S.D. stands for no significant difference in the level of a protein between red and white muscle. ${ }^{*}, * *$, and $* * *$ signify that the level of a protein was different by more than $20 \%, 40 \%$, and $50 \%$ respectively between red and white muscle. N.S.C. stands for no significant change in the amount of a protein due to nutritional stress. I. and D. respectively indicate relative increase or decrease in the content of a protein due to under-nutrition, and the stars indicate the extent of change i.e. more than $20 \%, 40 \%$, and $50 \%$ as mentioned before.

red muscle. The remaining proteins had identical concentrations in both muscles.

Various proteins in this fraction responded differentially in red and white muscles during underfeeding of broilers. In white muscle, the level of all proteins increased except those of $160 \mathrm{~K} \leq, 43 \mathrm{~K}$, and low molecular weight $(<22 \mathrm{~K})$ proteins which decreased in underfed broilers. In contrast, most of the proteins in this fraction of red muscle were not affected by under-nutrition. Only the level of $45 \sim 50 \mathrm{~K}$ proteins decreased, and that of $43 \mathrm{~K}$ increased more than $20 \%$ due to sub-maintenance feeding of broilers.

Proteins in $8,500 \times g$ precipitate. This fraction was mainly lysosomal and peroxisomal components of the sarcoplasm ${ }^{19 \sim 21)}$ of muscle. Several distinctions in the protein distribution in this fraction from red and white muscle can be seen (Fig. 2(c) and Table II). The content of $90 \mathrm{~K}, 35 \mathrm{~K}$, and $30 \mathrm{~K}$ proteins was greater, and that of $53 \mathrm{~K}, 40 \mathrm{~K}$, and low molecular weight $(\leq 22 \mathrm{~K}$ ) proteins was less in white muscle than in red muscle from well-fed broilers. However, the levels of $60 \mathrm{~K}$ and $48 \mathrm{~K}$ proteins were similar in both muscles.

All the proteins in this fraction from red muscle were insensitive to the nutritional state of the broilers, but a few from white muscle were greatly influenced by under-nutrition (Table II). While the magnitude of $60 \mathrm{~K}$ and $48 \mathrm{~K}$ rose, there was little change in the proportion of other proteins.

Proteins in $12,000 \times g$ precipitate of sarco- plasm. The $12,000 \times g$ precipitate represents mainly the heavy microsomal fraction of sarcoplasm. ${ }^{19 \sim 21)}$ SDS-polyacrylamide gel electrophoretogram of this fraction from red and white muscle reveals several differences (Fig. 2(d)). Lower levels of $94 \mathrm{~K}<, 53 \mathrm{~K}$, and $40 \mathrm{~K}$, and higher content of $60 \mathrm{~K}, 48 \mathrm{~K}, 35 \mathrm{~K}$, and $\sim 31 \mathrm{~K}$ are particularly obvious in white compared to red muscle (Table II). However, the amount of $94 \mathrm{~K}$ and low molecular weight $(\leq 23 \mathrm{~K})$ proteins was similar in both muscles.

The nutritional stress imposed on broilers affected the proteins in this fraction differently in red and white muscles. The relative concentration of $94 \mathrm{~K} \leq$ and $53 \mathrm{~K}$ protein increased, and that of $48 \mathrm{~K}, 40 \mathrm{~K}, \sim 31 \mathrm{~K}$, and low molecular weight $(\leq 23 \mathrm{~K})$ proteins decreased in white muscle from underfed broilers. In red muscle $94 \mathrm{~K}<$ and $53 \mathrm{~K}$ protein increased, and $48 \mathrm{~K}, 40 \mathrm{~K}$, and $\sim 31 \mathrm{~K}$ protein decreased due to under-nutrition. The content of other polypeptides in this fraction from both muscles was independent of the nutritional state of the broilers.

Proteins in $20,000 \times g$ precipitate of sarcoplasm. The $20,000 \times g$ precipitate represents mainly the medium microsomal components of sarcoplasm. ${ }^{19 \sim 21)}$ The SDS-PAGE pattern of this fraction (Fig. 2(e)) indicated that the levels of $60 \mathrm{~K}<$ and $44 \mathrm{~K}$ were similar in both muscles, but those of $60 \mathrm{~K}, 48 \mathrm{~K}, 35 \mathrm{~K}$, and $30 \mathrm{~K}$ proteins in this fraction were more in white than in red muscle by a margin over $20 \%$. On the other hand, the concentration of 
$40 \mathrm{~K}$ and low molecular weight ( $\leq 22 \mathrm{~K}$ ) polypeptides was less in white than in red muscle from ad libitum broilers (Table II).

Due to submaintenance feeding, the level of $60 \mathrm{~K}, 48 \mathrm{~K}, 35 \mathrm{~K}$, and $30 \mathrm{~K}$ protein increased in white muscle, but in red muscle only a $30 \mathrm{~K}$ protein increased and $35 \mathrm{~K}$ protein decreased (Table II).

Proteins in $100,000 \times g$ precipitate of sarcoplasm. The $100,000 \times g$ precipitate represents mainly the light microsomal components of sarcoplasm. ${ }^{19 \sim 21)}$ This fraction from red and white muscle was resolved into several proteins (Fig. 2(f)). The level of $60 \mathrm{~K}, 35 \mathrm{~K}$, and $31 \mathrm{~K}$ proteins was greater, but that of $53 \mathrm{~K}, 40 \mathrm{~K}$, and low molecular weight $(<31 \mathrm{~K})$ proteins was less in white than in red muscle (Table II). The relative amount of $94 \mathrm{~K} \leq$ and $48 \mathrm{~K}$ protein did not differ between muscles.

Only a few proteins in this fraction from red and white muscle were found to be sensitive to the nutritional state of the broilers. They were the $94 \mathrm{~K}, 60 \mathrm{~K}$, and $31 \mathrm{~K}$ proteins which were increased in white muscle, and the $60 \mathrm{~K}$ and $48 \mathrm{~K}$ proteins that were increased and decreased respectively in red muscle by nutritional stress (Table II).

Proteins in $100,000 \times g$ supernatant of sarcoplasm. The $100,000 \times g$ supernatant fraction of sarcomplasm is comprised mainly of true soluble proteins of the muscle, and these proteins are concerned mostly with the glycolytic and gluconeogenic pathways. $^{26)}$ On SDS-PAGE, this fraction from red and white fibers resolved into several proteins (Fig. 2(g)). The results in Table II show that the relative amount of $\sim 60 \mathrm{~K}, 48 \mathrm{~K}, 35 \mathrm{~K}, \sim 30 \mathrm{~K}$, and $21 \mathrm{~K}$ proteins was more, and that of $38 \mathrm{~K}$ protein was lesser in white than in red muscle of broilers. The $90 \mathrm{~K} \leq$ and low molecular weight $(\leq 20 \mathrm{~K})$ protein all had similar concentrations in both muscles.

Differential responses of proteins in this fraction to nutritional stress are also evident between red and white muscle (Table II). There was more than a $20 \%$ decrease in the level of $\sim 60 \mathrm{~K}$ and $35 \mathrm{~K}$ protein respectively in red and white muscle, whereas that of $90 \mathrm{~K} \leq$ protein is increased by $50 \%$ in both types of muscles. The amount of all other proteins remained stable in the event of nutritional stress imposed on the growing broilers.

\section{DISCUSSION}

The tonic (red) and phasic (white) muscles differ from each other in several respects, ${ }^{5} \sim 17$ ) but only a few differences have been reported at the molecular level. However, this study has revealed many conspicuous differences between red and white muscles with respect to the relative concentration of various porteins in different subcellular fractions (mitochondrial, lysosomal, microsomal, true soluble phase) of sarcoplasm, as is obvious from the protein profile on SDS-PAGE of each of these fractions (Figs. 2(a) to 2(g)). While the relative content of some molecular weight proteins was similar in both muscles, the others differed more than 20 to $50 \%$ between red and white muscle (Table II). Besides, the relative concentration of mitochondrial protein was more and that of total sarcoplasmic protein was less in red than in white muscle.

Gross under-nutrition has been shown to cause some reduction in the overall content of sarcoplasmic proteins (on a wet weight basis) in skeletal muscle of different species. ${ }^{27}$ 30) This apparent decrease is partly due to an increase in the water content that occurs in muscle during under-nutrition, ${ }^{30 \sim 32}$ ) and many of the differences disappear if the data are expressed on a fat-free, dry weight basis. However, in the earlier studies, the question as to how red and white skeletal muscle respond to gross nutritional deficiency was not addressed. It appears from this study that the overall sarcoplasmic protein content (on a wet weight basis) decreased to some extent only in white muscle as a result of under-nutrition, whereas little change was apparent in red muscle. This may be understandable in view of the fact that the rate of protein synthesis, as recorded by isotopic techniques, was found to be reduced only in fast glycolytic (white) muscles due to nutritional stress, but in slow oxidative (red) 
muscles the synthesis was not affected even during starvation of animals., ${ }^{2,33 \sim 35)}$

However, this generalization does not seem to apply to individual subcellular fractions in red or white muscle of broilers, because when the data on protein content of individual subcellular fractions was expressed as the percentage of overall sarcoplasmic protein content of red and white muscle from ad libitum fed and underfed broilers, a different picture emerged. The relative content of the mitochondrial fraction seemed to increase in red and decrease in white muscle from underfed chickens. Minor reductions in the lysosomal, microsomal, and soluble fractions also occurred in white muscle, but these changes were not apparent in red muscle as a consequence of nutritional stress (Table I). This suggests a differential rate of synthesis or degradation (i.e., turnover) of some subcellular fractions in red and white muscle in the event of restricted nutritional supply to the broilers.

Bates and Millward ${ }^{36)}$ have shown that the synthesis of sarcoplasmic proteins was less sensitive to starvation than myofibrillar proteins. A recent reported by Preedy and Garlick $^{35)}$ substantiated this finding. The overall sarcoplasmic protein content in our study hardly changed especially in red muscle due to nutritional stress, but the position at the molecular level was not the same. The protein profile on SDS-polyacrylamide gel electrophoretograms of subcellular sarcoplasmic fractions from red and white muscle of underfed and control broilers revealed quite distinct and interesting results. In each subcellular fraction, while the relative concentration of some proteins remained unaffected, that of others either increased or decreased by more than 20 to $50 \%$ due to nutritional stress. These findings suggest that a change in the overall protein concentration in sarcoplasm of a skeletal muscle may only be apparent rather than real as a result of under-nutrition, but significant changes in the level of some sarcoplasmic proteins do occur in red and white muscles not only at the subcellular but also at the molecular level. It is also suggested that in the case of limited nutritional supply, the content of some sarcoplasmic proteins is even greater than in muscles of well-fed animals. These changes may represent homeostasis mechanisms by which the organism adjusts its metabolic activity to adapt to adverse nutritional conditions for survival.

This is also obvious from several other studies which have shown a decrease in the activity of glutamate pyruvic transaminase, ${ }^{28,37)}$ and phosphorylase, ${ }^{38)}$ and an increase in the activity of alkaline protease, ${ }^{39)}$ cathepsin $\mathrm{B},{ }^{40}$ ) cathepsin $\mathrm{D},{ }^{41}$ ) and $\mathrm{Ca}^{2+}$-activated neutral protease ${ }^{42,43)}$ in skeletal muscle from nutritionally suffering animals. A study by Tasker and Turpule ${ }^{44)}$ indicated that the activity of succinate dehydrogenase and cytochrome $c$ oxidase decreased only in red muscle due to nutritional deficiency, whereas that of white muscle was not affected. In contrast, Goldspink and Warterson ${ }^{45)}$ found a change in the activity of some enzymes in white muscle due to starvation, but the red muscle was not affected. However, it may be emphasized that a change in enzymic activity does not necessarily mean a change in an enzyme content, because enzyme activity in living cells is regulated by two principal mechanisms: the genetic and the catalytic. ${ }^{46)}$ While the genetic control is concerned with a change in an enzyme content, the catalytic control involves role of activators and inhibitors, without affecting the amount of the enzyme.

Decker et $a l^{47)}$ have reported that although cathepsin D was not released into the cytoplasm from lysosomes in starved animals, its distribution was more in the sarcoplasmic reticulum of cardiac muscle. However, our study suggests several more such instances of alteration in some proteins at the subcellular level. It will be of interest to characterize further those protein molecules which experienced drastic changes at the subcellular level in response to nutritional stress.

Acknowledgment. Thanks are due to Dr. J. Ueda for his expert advice in keeping the experimental broilers free from diseases during this study, and to Dr. A. Hattori for his help in measuring the molecular weight of proteins on 
SDS-PAGE. One of the authors, Dr. A. Asghar (who wàs a visiting scientist from Pakistan), is appreciative of the Japan Society for the Promotion of Science for the award of a senior fellowship during this study.

\section{REFERENCES}

1) P. J. Garlick, M. Fern and V. R. Preedy, Biochem. J., 210, 669 (1983).

2) J. B. Li and A. L. Goldberg, Am. J. Physiol., 231, 441 (1976).

3) D. J. Millward, P. J. Garlick, D. O. Nnanyelugo and J. C. Waterlow, Biochem. J., 156, 185 (1978).

4) J. C. Waterlow, P. J. Garlick and D. J. Millward, "Protein Turnover in Mammalian Tissues and in the Whole Body," Elsevier, North-Holland, Oxford, 1978.

5) G. F. Gauthier, R. E. Burke, S. Lowey and A. W. Hobbs, J. Cell Biol., 97, 756 (1983).

6) B. R. Eisenberg and A. M. Kuda, J. Ultrastruct. Res., 54, 76 (1976).

7) O. A. Young, Meat Sci., 11, 123 (1984).

8) D. P. Cornforth, A. M. Pearson and R. A. Merkel, Meat Sci., 4, 103 (1980).

9) J. B. Peter, R. J. Barnard, V. R. Edgerton, C. A. Gillespie and K. E. Stempel, Biochemistry, 11, 2627 (1972).

10) C. R. Ashmore, G. Tompkins and L. Doerr, J. Anim. Sci., 34, 37 (1972).

11) W. T. Stauber and B. A. Schottelius, Exp. Neurol., 48, 524 (1975).

12) S. Sartore, S. Bormioli and S. Schiaffino, Nature (London), 274, 82 (1978).

13) G. Salviati, R. Betto and D. D. Betto, Biochem. J., 207, 261 (1982).

14) E. Cosmos, "The Physiology and Biochemistry of Muscle as a Food," Vol. 2, ed. by E. J. Briskey, R. G. Cassens and B. B. Marsh, The University of Wisconsin Press, Madison, 1970, p. 193.

15) U. Spamer and D. Pette, "Plasticity of Muscle," ed. by D. Pette, W. de Gruyter, Berlin, New York, 1980, p. 19.

16) M. Arnal, M. Ferrara and G. Fauconneau, "Nuclear Techniques in Animal Production and Health," Int. Atomic Energy Agency Report No. 205, 1976, p. 393.

17) P. C. Bates and D. J. Millward, Biochem. J., 214, 587 (1983).

18) A. Asghar, J.-I. Morita, K. Samejima and T. Yasui, Agric. Biol. Chem., 48, 2217 (1984).

19) C. de Duve, B. C. Pressman, R. Gianetto, R. Wattiaux and F. Appelmans, Biochem. J., 60, 604 (1955).

20) A. Ito, "Seitaimaku Jikkenho (in Japanese)," ed. by Y. Akamatsu, A. Asano, Y. Anraku, T. Ohmura, M. Fujita and S. Mizushima, Kyoritsu Shuppan, Tokyo,
1974, p. 268.

21) J.-I. Morita and T. Yasui, Agric. Biol. Chem., 49, 1397 (1985).

22) O. H. Lowry, N. J. Rosebrough, A. L. Farr and R. J. Randall, J. Biol. Chem., 193, 265 (1951).

23) G. L. Peterson, "Methods in Enzymology," Vol. 91, ed. by C. H. W. Hirs and S. N. Timasheff, Academic Press, New York, 1983, p. 75.

24) U. K. Laemmli, Nature (London), 227, 680 (1970).

25) G. W. Snedecor, "Statistical Methods," 6th ed. Iowa State University Press, Ames, 1966.

26) R. K. Scopes, Biochem. J., 161, 253 (1977).

27) J. W. T. Dickerson and R. C. McCance, Brit. J. Nutr., 14, 331 (1960).

28) M. Yamaguchi and M. Kandatsu, Agric. Biol. Chem., 31, 776 (1967).

29) A. Asghar and M. T. M. Yeates, Agric. Biol. Chem., 43, 437 (1979).

30) A. Asghar, A. M. Pearson, W. T. Magee and M. A. Tahir, J. Nutr., 111, 1343 (1981).

31) R. Smith, Clin. Sci., 19, 275 (1960).

32) E. F. Terroine, E. Brenckmann and H. Feuerbach, Archv. Inst. Physiol., 20, 466 (1922).

33) K. N. Frayn and P. F. Maycock, Biochem. J., 184, 323 (1979).

34) M. J. Rennie, R. H. T. Edward, D. Halliday, D. E. Matthews, S. L. Wolman and D. J. Millward, Clin. Sci., 63, 519 (1982).

35) V. R. Preedy and P. J. Garlick, Biochem. J., 214, 433 (1983).

36) P. C. Bates and D. J. Millward, Biochem. Soc. Trans., 6, 612 (1978).

37) J. H. Ashley and E. H. Fischer, Brit. J. Nutr., 21, 661 (1970).

38) Y. Matsuda and E. H. Fischer, "Intracellular Protein Turnover," Vol. 4, ed. by R. T. Schimke and N. Katunuma, Academic Press, New York, 1975, p. 177.

39) T. Noguchi, E. Miyazawa and M. Kametaka, Agric. Biol. Chem., 38, 253 (1974).

40) W. N. Schwartz and J. W. C. Bird, Biochem. J., 167, 811 (1977).

41) K. Lundholm, L. Ekman, I. Karlberg, S. Edstrom and T. Schersten, Cancer Res., 40, 1680 (1980).

42) G. J. Seperich and J. F. Price, Meat Sci., 2, 41 (1978).

43) N. Arakawa, M. Takashima, T. Kurata and M. Fujimaki, Agric. Biol. Chem., 47, 1517 (1983).

44) K. Tasker and P. G. Turpule, Biochem. J., 92, 391 (1968).

45) G. Goldspink and S. E. Warterson, Acta Histochem., 40, 16 (1971)

46) K. G. Serimgeour, "Chemistry and Control of Enzyme Reaction," Academic Press, London, 1977.

47) R. S. Decker, J. S. Crie, A. R. Poole, J. T. Dingle and K. Wildenthal, Lab. Invest., 43, 197 (1980). 